УДК 165.12-044.7Бер,Гус

DOI 10.35423/2078-8142.2019.3-4.07

I. I. Іванюк, аспірантка кафедри культурологї̈ та філософії Національного університету "Острозька академія» м. Острог, Україна e-mail: e-mail: IvaniukIrishk@i.ua ORCID: https://orcid.org/0000-0002-7417-1617

\title{
«ТЕМПОРАЛЬНІСТЬ СВІДОМОСТІ» ТА «СВІДОМІСТЬ ТЕМПОРАЛЬНОСТІ» (БЕРГСОН VERSUS ГУССЕРЛЬ)
}

У статті здійснено аналіз історико-філософського иляху двох основних методологій дослідження темпоральності до появи фундаментальної онтології М. Гайдеггера, щьо названо «темпоральність свідомості» та «свідомість темпоральності». Підгрунтя «темпоральності свідомості» сягає психологізму неоплатоніків, згодом, через новочасний емпіризм, - аж «творчої еволючії» А. Бергсона. «Свідомість темпоральності» базується на концепті «тепер», що глибоко аналізував Аристотель, згодом Августин. Дана методологія утвердилась згодом в якості новочасного трансиендентального суб'єкта, а згодом проявилася у феноменологї Гуссерля. Основні контраверсії цих підходів полягають у можливості об'єктивачії часового досвіду. Периа методологія бере в лапки «Більше-не» $i$ «Ще-не» часовості, а друга - точку «тепер». Проаналізувавши підгрунтя кожної з них, ми вийшли на темпоральні концепти двох визначних мислителів XIX-XX ст. - А. Бергсона та Е. Гуссерля. Порівняння їх контраверсійних точок зору подано у висновку.

Ключові слова: темпоральність, свідомість, психологізм, феноменологія, «тепер».

Часовість є особливим феноменом, що відкриває перед філософським мисленням онтологічний грунт прояснення багатьох проблем у сфері мнемології, герменевтики, гносеології, феноменології, філософії історії та соціальної філософії. Саме тому вона так

(C) Іванюк I. I., 2019 
цікавила мислителів найдавніших епох. Особливого розмаху дослідження теми темпоральності набуло у епоху Нового часу, оскільки у цей період відбувається відокремлення iдеї часу та простору від мислення їх у конкретній емпіричній іманентній прив'язці. Зміст часовості проглядається як форма споглядання, а не окремо існуюча без суб'єкта пізнання дійсність. Наукові дослідження даної тематики знаходимо у Ж. Грондена, В. Бімеля, Ж. Бофре, Т. Шварца, А. Чернякова, П. Гайденко, Г. Хюні, І. Блауберг, Ф. Нетеркотта, Б. Бабиніна, Г. Марселя, а серед українських дослідників - у працях В. Кебуладзе, А. Дахнія, В. Ханжи, Є. Мулярчука, В. Колоярцева. Крім того, є підстави вважати, що у період від Нового часу до появи фундаментальної онтології М. Гайдеггера (а саме за цих часів темпоральність мислилась переважно крізь призму свідомості) як ніколи актуальними простежується дві основні і водночас котраверсійні методології дослідження темпоральності. Одна з них грунтується на психологізмі часу (посткласичних апогеєм якого видається «творчий інтуїтивізм» А. Бергсона), інша - у спробах об'єктувати суб' єктивний за своєю природою досвід часовості (з появою найбільш впливового у західноєвропейському мисленні напряму феноменології часу Е. Гуссерля). За завдання поставлено дослідити історико-філософські корені даних методологій, проаналізувати їх та здійснити порівняння методологічних концепцій темпоральності у А. Бергсона та Е. Гуссерля, погляди яких $є$ апогеєм історії філософії кожного із запропонованих напрямів.

Темпоральність свідомості: Бергсон. Про поняття «темпоральності свідомості» в історії філософії маємо право говорити, вочевидь, відколи активно впроваджується у філософську мову поняття свідомості як таке, а саме - у Новий час. Але до цього був пройдений певний мисленнєвий шлях, зокрема в осмисленні часу свідомості. Зокрема, античний час має характер рухливої емпірії космосу, на противагу його перманентній, сталій гармонії та незмінності. Загальна інтенція епохи - це об'єктивний час, іманентний космосу (за виключенням, щоправда, неоплатоніків). У Платона час лише «рухлива подоба» трансцендентного світу ідей. Аристотеля також цікавить іманентний космосу фізичний час та його вимір ( у цього мислителя вже є натяк на те, що «без душі не може 
існувати і час» [1, с. 157]). Ця думка утверджена неоплатоніками, оскільки тут саме психологізм часу стає основою пояснення його природи (зокрема, у Плотіна). Душа тяжіє до змінюваності, а часовість виступає іiі онтологічним грунтом. Середньовічне мислення відрізняється від античного розумінням космосу і природи вічності. В обох випадках (як в Античності, так і в Середньовіччі) час ставиться на противагу вічності, але «антична» вічність - це вічність іманентна вічному космосу. Часовість як мінливість виходить за рамки кола перманентності (що пропонує осмислювати час на противагу вічності, а остання являє собою незмінний іманентний космос). «Середньовічна» вічність - це вічність, трансцендентна світу, який осмислюється створеним, а Творцем іманентного світу $\epsilon$ трансцендентний Бог, буття якого і $є$ Вічністю, а час з'являється разом із творенням світу ex nihilo («з нічого»), тобто час, що виникає 3 появою світу, є ознакою створеної природи. Крім онтологічної складової середньовічної темпорології, що пов'язана 3 диференціацією часу і Вічності, ми не можемо оминути увагою принципову, в даному контексті, тему антропологічної віхи у середньовічному осмисленні часу. Остання пов'язана з ім'ям Августина Блаженного. Ця віха стала важливим підгрунтям для появи новочасної філософії зі специфікою іiі трансцендентального суб'єкта, а також феноменології. У ній проглядаються риси новочасного розуміння свідомості як неподільної точки часовості, актуалізатора часових модусів, здатності людської душі з'єднувати розпорошені образи досвіду та об'єктів зовнішнього світу воєдино, часовість можна розглядати онтологічним грунтом ідентичності. Людська душа, за Августином, є унікальною в тому сенсі, що лише у ній на тлі усього, що існує, є три часи: теперішнє минулого (пам'ять), теперішнє теперішнього (увага) і теперішнє майбутнього (очікування). Аналізуючи Новочасні змісти щодо філософського осмислення часу, ми звертаємо увагу на відмінності емпіристів (які відіграли ключову роль у появі підходу, що ми назвемо «темпоральність свідомосmi») та раціоналістів цього періоду (яких пов'язуємо із започаткування методології «свідомість темпоральності»). Раціоналісти виходили $з$ поняття субстанції. Відповідно, природа часу була пов'язана $з$ його статусом відносно останньої. Відтак, сам час виступає атрибутом не іманентним світу, а лише умовним «плацдар134

Institute of Philosophy of H. S. Skovoroda of NAS of Ukraine 
мом» можливостей світу речей, тобто може існувати без них. Емпіристи (Дж. Локк, Д. Г’юм) обгрунтовують темпоральність 3 точки зору ії психологізму, який пов'язує час із життям душі (що мав місце вже у Плотіна, а згодом - і у Августина). Текучість вражень свідомості у їх послідовності, їі неперервна змінність і $є$ природою часовості, на думку представників цього філософського напряму.

Новочасний емпіризм, який вбачав основну функцію свідомості у з'єднуванні (а саме - як апріорний елемент об'єднання емпіричних фактів свідомості) дав поштовх для нових посткласичних напрямів, зокрема «duree» («тривалість») А. Бергсона. Мислитель вказував, що тривалість має зовсім інакші характеристики, ніж природний час. Філософ вважає, що вдаючись до розгляду часу із залученням просторових характеристик, ми залишаємось осторонь справжнього розуміння феномена. На думку Бергсона, навіть мислення філософа не може бути позбавленим його особистого (певною мірою часового) досвіду: «Філософська інтуїція не позачасова, iii носієм є не абстрактний суб'єкт, а конкретна людина, учасник i свідок історичних подій» [3, с. 12]. У своєму розгортанні ідеї тривалості Бергсон відкидає будь-які абстракції. Його цікавить «реальна людина, реальний час, реальний життєвий досвід» [3, с. 75]. Емпірія для Бергсона визначалась принципово атрибутом часовості, а не просторовості. Речі та предмети зовнішнього світу не $\epsilon$ самі по собі для нас дані. Вони служать лише відкриттям для нас самої тривалості. Речі, так би мовити, стають освоєними нами у нашому до них відношенні. Умовою такого освоєння і $€$ сама тривалість людської свідомості. Критикуючи Канта за те, що він «відірвав простір від його змісту» [2, с. 166], А. Бергсон намагається довести: будь-яка річ, з якою ми контактуємо у нашому буденному житті, сама по собі знаходиться ззовні по відношенню до нас самих, нашої свідомості. Але стан свідомості, який ми маємо за участі тієї чи іншої речі, - це вже наше внутрішнє суб'єктивне надбання. У такому випадку вся сукупність вражень, притаманна тій чи іншій свідомості, є їх неперервною тривалістю. Аби вказати на відмінність часу з простором, Бергсон щодо простору вживає прикметник «однорідний» - саме це означення, на його думку, доводить його несумісність 3 тривалістю. Якби час покладав однорідність, то це означало б, що він є зовнішнім по відношенню до суб'єкта, який 
ним живе. Насправді ж, у повсякденному житті людська свідомість не знає такої однорідності, адже вона завжди насичена якимось станом, результатом відчуттів, а вони, своєю чергою, постійно змінюють один одного, до того ж змінюють так, що ця зміна відбувається безперервно - тому свідомість постійно перебуває у тривалості. Постійне приєднання різних станів покладається за основу тривалості. Інтенсивність враження (або просто відчуття) не мала б жодного значення, якби не змінність чи якісний перехід. Анрі Бергсон називає тривалість «процесом», органічною цілісністю, тому одним із найважливіших моментів duree визначимо властивість неперервності. Ось у цьому, власне, і полягає ключова відмінність свідомості та матерії, на думку філософа. Матерія сама по собі і не може зберігати минуле - це прерогатива виключно свідомості; в тому сенсі Бергсон називає матерію «мертвою». Наступна ознака бергсонівської тривалості - неповторюваність кожного з ії моментів. Свідомість ніколи не лишається у статичному стані, а завжди йде далі, тому будь-яка спроба повторити момент завершується неуникненною поразкою. Кожен теперішній стан буде інакшим по відношенню не лише до наступного і попереднього, а й до усього цілого загалом. Як це пояснити? Якби навіть нам заманулось повторити якийсь 3 моментів, то сама якість такого повтору була б вже зумовлена новим попереднім і новим наступним. Ще однією ознакою тривалості є визначимо психологічний детермінізм - «кожен наступний стан, наче кориться попередньому» [2, с. 268], а «найбільш сильний зі станів виявляє найбільш сильний вплив і тягне за собою решту» [2, с. 277]. Тому філософ наголошує на особливостях пов'язаних, по-перше, з екстазами часу, по-друге - 3 тілесно-свідомою єдністю: минуле присутнє в нашій тривалості як нашарування образів, тілесність бере участь в актуалізації, тобто переживанні теперішнього досвіду. Цікаво те, що в даному огляді минуле, залишаючись виключно в тривалості (захованим у пам'яті), за зручною на те нагодою, може і актуалізуватись у теперішньому. Майбутне тривалості присутнє там, де людина може очікувати наслідки своєї актуалізації, своєї дії, вибору та рішення, тобто в «тепер» закладає умови майбутнього досвіду. За посередництвом нашого тіла ми актуалізовуємо свій теперішній досвід, але оскільки пам'ять як особливе психологічне явище залишається 
присутньою у нашій тривалості завжди, навіть тоді, коли не має змоги актуалізації, остання ж у сприятливий для того момент таки може здійснюватися... Отже, загалом «тривалість як «тканина психології життя» визначає своєрідність кожної особи, взятої в ії історичному становленні, розгортання ії духовних сил і можливостей» [3, c. 104].

Свідомість темпоральності. Гуссерль. У перспективі темпоральної онтології Новий час став переломним ще в одному сенсі, а саме - завдяки появі iдеї часу, що стало підгрунтям класичного розгляду його як форми споглядання, суб'єктивної форми, а не певної емпірично-субстанційної дійсності, яка існує поза суб'єктом пізнання. Цей переломний момент дав представникам трансцендентальної філософії можливість намагатись об'єктивувати, трансцендентувати часовість, де можемо говорити про заявлену у заголовку «свідомість темпоральності». Трансцендентальний суб'єкт розглядається як позачасовий, оскільки «мисленнєвий акт відбувається лише тут і зараз, у цій ділянці простору і в цей момент часу» [6, с. 17], тобто акт мислення не передбачає природньої для темпоральності тяглості, так званої ретенційності.

Особливу роль у новочасній філософії відіграв концепт Я. Доцільним видається прослідкувати корені останнього в контексті темпоральної проблематики до-новочасної філософії та рецепцію останньої у трансцендентальній та емпіричній філософії вже Новочасного періоду. У темпоральному відношенні йдеться про концепт «тепер», оскільки саме він є часовою точкою свідомості, власне Я, чисте споглядання. Вперше концепт «тепер» ми зустрічаємо ще в Античності, згодом, у дещо видозміненому обгрунтуванні, у Середньовіччі; він утримує свій онтологічний зміст і в новочасному осмисленні свідомості. Якщо Платон приділяє більшу увагу метафізичному змісту часу як атрибуції множинного та противагу Єдиного, то Аристотель - межовому концепту «тепер» як вирішальному в аспекті вимірювання. «Тепер» Аристотель не відносить до частин часу. Філософ вказує, що «тепер» за своїм субстратом $\epsilon$ незмінним, але цей модус щоразу належить інакшому буттю у часі - тому кожен раз видається відмінним: «Тіло, що рухається, лишається тим самим - точкою, каменем або іншим чимось, а за визна- 
ченням стає іншим» [1, с. 149]. «Тепер» $є$ чимось неділимим» [1, с. 185], і в ньому самому «немає ніякого руху» [1, с. 186]. У зв'язку із особливостями Середньовічної темпорології поглянемо на августинівську трьохмодусну модель часу, де вирішальним $\epsilon$ саме «тепер» як інструмент актуалізації: теперішнє минулого, теперішне теперішнього та теперішнє майбутнього. Майже в усіх мислителів епохи концепт «тепер» відіграє роль «вікна у вічність» для підтвердження трансцендентного джерела виникнення часу. «Тепер» і є сама свідомість, яка має здатність актуалізувати, вона «об'єднує образи багатоманітного докупи» [4, с. 66]. Новочасний дух раціоналізму визначав, що «неділимим, єдиним у людині $є$ розум, звідси слово cogitare» [4, с. 66]. У Р. Декарта тривалість постає атрибутом «чогось постійного в мінливому» [4, с. 100]. Д. Г’юм порушує питання безкінечної ділимості точки та можливості існування ideї часу i простору (як споглядальної можливості) окремо від їх емпірії - вражень, емоцій, що мають вони безпосередньо. Це стало рушієм Новочасного раціоналізму та підгрунтям «критичного» періоду Канта з його вже трансцендентальною свідомістю та якісно новим у філософії підходом до часу і простору як апріорних форм чуттєвості, чистої форми споглядання. А поява наприкінці XIX ст. трансцендентальної феноменології Е. Гуссерля стала не лише проривом у філософуванні, а і його новим методом в історії філософії як можливість трансцендентувати, об'єктивувати будьякий досвід, зокрема досвід часовості. Тому саме його праці «Лекції з феноменології внутрішньої свідомості часу» (1928) наразі присвячується особлива увагу як апогею в історії філософії та методологічного результату спроб трансцендентувати часовість, що ми назвали «свідомістю темпоральності». Гуссерль починає свою працю з означення дійсності. Він відзначає, що реальний час не $\epsilon$ феноменологічно даним для нас, адже «це не є час світу досвіду, але іманентний час протікання свідомості» [5, с. 6]. На думку філософа, об'єктивний час - це певна феноменальна дійсність, до якої ще потрібно прийти. Мислитель розрізняє «часове, щуо відчувається» [9] - через нього схоплюється лише відношення до об'єктивного часу, і «часове, що сприймається» [9] - саме воно позначає для Гуссерля об'єктивний час. Складність отримання об'єктивного часу полягає в тому, що він не існує субстанційно, 
залишаючись змінним потоком свідомості. Такий час віднаходиться через об’ єктивування «щойсткості» часових структур, яка криється швидше у зв'язках і відношеннях, а також сталих закономірностях модусів та часового потоку взагалі: «об'єктивність у властивостях схоплювання і в закономірностях, що належать до сутності цих властивостей» [5, с. 10].

Звертаючись до аналізу Гуссерлем часових модусів відзначимо, що минуле, на його думку, у феноменологічному сенсі не минає і не зникає, а відбувається лише його відсування у часі. Відтак, будь-яке теперішнє і навіть майбутнє $є$ наперед приреченими на відсування такого роду (ще до реальної актуалізації) - таким чином, у тривалості відбувається постійна зміна, постійний перебіг, зсув актуального. Тому точка «тепер» завжди знаходиться в ретенції минулого на актуальне. Цікаво, що модуси минулого i майбутнього можуть впливати на хід чуттєвих уявлень не лише попереднього (про що говорив і Бергсон), а й наступного модусу. Філософ стверджує, що часова тривалість свідомості ніколи не отримана нами повністю і відразу: тривалість - це часове розгортання, і воно завжди послідовне. Відтак, суть феноменологічного підходу до часу у тому, щоб споглядальним модусом «тепер» схопити «ціле, частини якого послідовні» [5, с. 23]. I хоча, на думку Гуссерля, частини цілої тривалості існують «у свідомості один за одним, але вони опиняються у межах одного і того самого цілісного акту» [5, с. 24]. Філософ переконує, що емпірично ми зустрічаємо принципове нерозділення часових проміжків, називаючи часове буття «протіканням». Останнє являє собою зв'язану єдність, і жодна 3 ділянок сама по собі нічого не вартує, а наше їх умовне розділення - це лише абстракція. Емпірично сприйняття межі (зокрема межі «тепер») не існує. Межа може створюватись штучно, завдяки феноменологічному методу, що ми назвали «свідомість темпоральності». І хоча точка теперішнього повсякчас слугує актуалізатором, часовість протікає у спектрі інтенцій на минуле чи майбутнє. Якщо з минулим у цьому сенсі все зрозуміло, оскільки ми вже зустрічали в історії філософії думку про факт накладання минулого досвіду на актуальне сприйняття і в попередніх філософів (Е. Гуссерль навіть ототожнює поняття спогаду і сприйняття), то майбутнє потребує детальнішого прояснення. Цей модус наперед 
покладає себе в очікуванні (це ми знаємо ще від Августина i А. Бергсона), але у феноменологічному сенсі, зокрема для Гуссерля, очікування розкриває себе, коли очікуване настає як теперішнє, а саме - очікування (воно, до речі, методологічно може також ставати об'єктивованим), водночас, відсувається в минуле: «якщо майбутнє стало теперішнім, то теперішнє стало відносно минулим» [5, с. 60]. Розглядаючи об'єктивацію темпорального досвіду, Гуссерль наштовхує на думку про те, що дана об'єктивація близько підходить до проблеми ідентичності. У кожному змісті відчуття об'єктів спостерігається певна «щойсткість», і вона лишається актуальною у перерізі часових змін. «Йдеться про постійний момент індивідуації, в якому має своє джерело часова позиція» [5, с. 70]. Гуссерль відзначає, що саме часовість стає свідченням та індикатором даного факту, тому називає індивідуальність «темпоральною формою відчуття» [5, с. 71]. Феноменолог пропонує розрізняти «свідомість (потік) і явище (іманентний об'єкт)» [5, с. 80] у темпоральному сприйнятті.

Феноменологічний метод усвідомлення часу прагнув об'єктивувати те, що за природою є суто суб'єктивним та надати обрисів наукової, математичної строгості тому, що звично просто «переживати». Він став результатом тривалого шляху мислення, лінії якого проходять крізь німецьку класику, появу новочасного суб'єкта, модусної моделі Августина і аж до Платона. Оскільки в даному огляді ми вирішили поглянути на два кардинально протилежні підходи до вивчення темпоральності разом, то спробуємо дослідити деякі їх контраверсійні точки. Швейцарський науковець Френсіс Нетеркотт називає тривалість, яку досліджував Бергсон, «життєвим часом» [7, с. 21]. Первинно справою темпоральної філософії Бергсона і було намагання вказати на те, що час, яким живе людина, не повинен постійно вдаватися у просторову характеристику математичного чи фізичного (одним словом об'єктивуючого часу). Е. Гуссерль називав даний підхід психологізмом і критикував його, пропонуючи шлях об'єктивування досвіду, де віднаходиться «свідомість єдиного, гомогенного, об'єктивного часу» [5, с. 73]. У часовому потоці відбувається «перетворення Тепер на Більше-не [Тепер], а з іншого - Ще-не[Тепер] на Тепер, де, крім того, існує дещо таке, як загальна форма Тепер, рівність вза140

Institute of Philosophy of H. S. Skovoroda of NAS of Ukraine 
галі в модусі потоку» $[5,81]$. Пошук даної форми рівнозначний пошуку об'єктивного в темпоральному потоці. Феноменологічний шлях «свідомості темпоральності» - це шлях, де «тепер», умовно кажучи, бере в лапки «більше-не» і «ще-не» темпоральної тривалості, який сповнений індивідуалізованим досвідом «що», тобто «в Тепер споглядається Не-Тепер» [5, с. 62]; тоді як у межах методологічного шляху осягнення часу як «темпоральності свідомості» в лапках опиняється «тепер» як точка умовного з'єднання та роз'єднання загального темпорального потоку. Коли йдеться про «часовість темпоральності», зокрема у випадку з Бергсоном, то тіло тут перебуває у рівнозначному зі свідомістю впливі на тривалість, у випадку зі «свідомістю темпоральності», тіло і тілесність дещо нівелюється, оскільки під збільшене скло беруться зовсім інші феномени. Бергсон принципово уникає можливості оцінювати час як об'єктивний і однорідний, вважаючи, що у такий спосіб, ми «омертвляємо» його природу, накладаючи на суб'єктивну, живу тривалість, методологію мертвої матерії, якій притаманний механіцизм. На думку Бергсона, неможливість тривалості бути однорідною - це яскрава особливість, що відрізняє ії від простору. Гуссерль, як виходець зі школи німецької класики, де час (так само, як і простір) форми (чисті форми споглядання), оцінює однорідність часу як обов'язкову умову його об'єктивності, адже однорідність виключає зміну, а змінюється завжди «щось». Отже, феноменологічний метод має вийти за межі такої «щойсткості», щоб методологічно схопити ii. Логічним завершенням темпорального дослідження Бергсона стає тема свободи, оскільки свідомість у її тривалості постає тут активним «флюгером» освоєння досвіду, а також джерелом творчості. У Гуссерля такою темою стає ідентичність, яку він пов'язує з фактом індивідуації досвіду, адже у темпоральному потоці залишається дещо незмінне, самототожне. 


\section{ЛІТЕРАТУРА}

1. Аристотель. Сочинения. В 4-х тт. Т. 3. Москва : Мысль, 1981. C. 59-262.

2. Бергсон А. Творческая эволюция. Материя и пам'ять. Москва : Харвест, 1999. 1408 с.

3. Блауберг И. Анри Бергсон. Москва : Прогрес - традиція, 2003. $672 \mathrm{c}$.

4. Гайденко П. Время. Длительность. Вечность. Проблема времени в европейской философии и науке. Москва : Прогрес - Традиция, 2006. $464 \mathrm{c}$.

5. Гуссерль Э. Феноменология внутреннего сознания времени / пер. и предисловие В. И. Молчанов. Москва : Издательство «Гнозис», 1994. $162 \mathrm{c.}$

6. Зайцев М. Ранні грецькі філософи (від Фалеса до Демокріта). Острог : Видавництво національного університету «Острозька академія», 2016. $178 \mathrm{c.}$

7. Нэтеркотт Ф. Философская встреча: Бергсон в России. Москва : Модест Колеров, 2008. 432 с.

\section{REFERENCES}

1. Aristocle. (1981). Works in four volumes. Moskow: Mysl. [In Russian].

2. Bergson, A. (1999). Creative evolution. Matter and memory. Moskow: Harvest. [In Russian].

3. Blauberg, I. (2003). Anri Bergson. Moskow: Progries-traditsyia. [In Russian].

4. Haidenko, P. (2006). Time. Duration. Eternity. Moskow: Progriestraditsyia. [In Russian].

5. Husserl, E. (1994). Phenomenology of the internal consciousness of time. Moskow: Gnozis. [In Russian].

6. Zaytsev, M. (2016). Early Greek philosophers. Ostroh: Publishing by National University of Ostrog Academy. [In Ukrainian].

7. Neterkot, F. (2008). Philosophical meeting. Bergson in Russia. Moskow: Modest Kolierov. [In Russian]. 


\title{
Irina Ivanyuk
}

Post-Graduate Student (PhD)

Departments of Cultural Studies and Philosophy

The National University of «Ostroh Academy»

Ostroh, Ukraine, e-mail: IvaniukIrishk@i.ua

ORCID: https://orcid.org/0000-0002-7417-1617

\section{"Temporality of consciousness» and "consciousness of temporality" (Berg- son versus Husserl).}

\begin{abstract}
This article traces the historical and philosophical path of two major methodologies for the study of temporality to the emergence of the fundamental ontology of M. Heidegger, which was called «temporality of consciousness» and «consciousness of temporality.» The roots of the "temporality of consciousness» are traced back to the psychologism of the Neo-Platonists, and later to the philosophers of modern empiricists and to Bergson's "creative intuition" where the body is considered inseparably linked to consciousness. We base the methodology of «consciousness of temporality» in the concept of «now», the analyst of which was still in Aristotle, later Augustine, and established itself in the Modern Transcendental Subject, and then manifested in the phenomenology of Husserl where the body and physicality are somewhat offset, since the magnifying glass is completely different phenomena.

The main contravers of thinkers are seen in the possibility of objectifying temporal experience. Bergson essentially avoids the possibility of evaluating time as objective and homogeneous, believing that in this way we «mortify» his nature by imposing a subjective, living duration, a methodology of dead matter. According to Bergson, the impossibility of duration to be homogeneous is a striking feature that distinguishes it from space. Husserl analyzed time (just like space) forms (pure forms of contemplation), considers the homogeneity of time as a necessary condition for its objectivity, because homogeneity eliminates change. So, the phenomenological path is the path where now, relatively speaking, it takes in quotes More-not and Not-yet-temporal duration, and «temporality of consciousness» takes in quotes the point «now» as a conditional place of actualization of past and future.
\end{abstract}

Keywords: temporality, consciousness, psychology, phenomenology, «now». 


\section{Ирина Иванюк}

аспирантка кафедры культурологии и философии Наиионального университета «Острожская академия»

2. Острог, Украина, e-mail: IvaniukIrishk@i.uа

ORCID: https://orcid.org/0000-0002-7417-1617

\section{"Темпоральность сознания" и "сознание темпоральности" (Бергсон versus Гуссерль).}

\section{Аннотация}

В данной статье рассмотрен историко-философский путь двух основных методологий исследования темпоральности до появления фундаментальной онтологии М. Гайдеггера, которые названы «темпоральность сознания» и «сознание темпоральности». Почва «темпоральности сознания» проявляется из психологизма неоплатоников, впоследствии через эмпиризм Нового времени до «творческой эволюиии» А. Бергсона. «Сознание темпоральности» базируется на кониепте «теперь», который глубоко анализировал Аристотель, впоследствии Августин. Эта методология утвердилась в качестве трансиендентального субъекта, а впоследствии проявилась в феноменологии Гуссерля. Основные котраверсии этих подходов заключаются в возможности объективачии временного опыта. Проанализировав почву каждой из них, мы вылил на темпоральные конщепты двух выдаюшихся мыслителей ХІХ-XX см.: А. Бергсона и Э. Гуссерля. Сравнение их контраверсионных точек зрения представлены в заключении.

Ключевые слова: темпоральность, сознание, психологизм, феноменология, «теперь». 